\title{
Epstein-Barr Virus-Associated Classical Hodgkin Lymphoma and Its Therapeutic Strategies
}

\author{
Im-Soon Lee* \\ Department of Biological Sciences and Center for Biotechnology Research in UBITA (CBRU), Konkuk University, Seoul 143-701, \\ Republic of Korea
}

\begin{abstract}
Over the past few decades, our understanding of the epidemiology and immunopathogenesis of Hodgkin lymphoma (HL) has made enormous advances. Consequently, the treatment of HL has changed significantly, rendering this disease of the most curable human cancers. To date, about $80 \%$ of patients achieve long-term disease-free survival. However, therapeutic challenges still remain, particularly regarding the salvage strategies for relapsed and refractory disease, which need further identification of better prognostic markers and novel therapeutic schemes. Although the precise molecular mechanism by which Epstein-Barr virus (EBV) contributes to the generation of malignant cells present in HL still remains unknown, current increasing data on the role of EBV in the pathobiology of HL have encouraged people to start developing novel and specific therapeutic strategies for EBVassociated $\mathrm{HL}$. This review will provide an overview of therapeutic approaches for acute EBV infection and the classical form of $\mathrm{HL}$ (cHL), especially focusing on EBV-associated HL cases.
\end{abstract}

Key Words: Classical Hodgkin lymphoma, EBV, Hodgkin and Reed-Sternberg cells

\section{INTRODUCTION}

Lymphoma is a type of cancer involving cells of the immune system, and has two major categories: Hodgkin lymphoma $(\mathrm{HL})$ and all other lymphomas (non-HL). Although the two types may display the same symptoms, they are readily distinguishable via microscopic examination, and differ in the way they develop, spread and are treated. $\mathrm{HL}$ is a unique clinicopathological disorder characterized by the rare presence of malignant cells (usually accounting for $0.1 \%$ to $10 \%$ of the cells in the total tumor mass) in a background of a nonneoplastic cellular microenvironment comprising $\mathrm{T}$ - and $\mathrm{B}$ lymphocytes and other cell types (Weiss et al., 1999). In the United States, about 8,500 new cases of HL were expected to be diagnosed in 2010, and the overall incidence is increasing each year (Maggioncalda et al., 2011).

Although the pathogenesis of $\mathrm{HL}$ is still largely unknown, the association of HL with Epstein-Barr virus (EBV) infection has been demonstrated in many reports. For examples, HL patients show elevated antibody titers to EBV antigens (Levine et al., 1971), and the risk of developing $\mathrm{HL}$ is increased up to three-fold in population that have experienced infectious mononucleosis caused by primary EBV infection (Gutensohn

www.biomolther.org

Open Access http://dx.doi.org/10.4062/biomolther.2011.19.4.398

pISSN: 1976-9148 elSSN: 2005-4483

Copyright $\odot 2011$ The Korean Society of Applied Pharmacology and Cole, 1980), and EBV DNA/RNA can be detected in HL tissues (Brink et al., 1997), suggesting that as a primary event in the development of this disease, EBV infection may play a very crucial role in the pathogenesis of $\mathrm{HL}$.

According to a population-based cohort study, the frequency of EBV associated $\mathrm{HL}$ among total $\mathrm{HL}$ cases varies from 30 to $50 \%$ (in certain cases even higher; $>90 \%$ in developing and underdeveloped countries, and $>95 \%$ in HIV associated cases), and most of them appear in classical Hodgkin lymphoma (CHL), the major type of HL (Herbst et al., 1991; Pallesen et al., 1991; Ambinder et al., 1993; Leoncini et al., 1996). Since EBV is an oncogenic virus that is able to subvert cellular processes supporting growth and survival, the approach to unravel the function of latent EBV genes expressed in $\mathrm{CHL}$ tissues will provide strategies for more novel and targeted therapies for $\mathrm{cHL}$ patients. Thus, this review, based on considerable progress recently made regarding the pathways related to the generation of $\mathrm{cHL}$ over the past years, presents a summary of EBV antiviral drugs, the main characteristics of the disease entities, the data on the possible role of EBV in the pathogenesis of EBV-positive HL, and current therapeutic options including immunotherapy.

Received Aug 23, 2011 Revised Aug 26, 2011 Accepted Aug 26, 2011

\section{*Corresponding Author}

E-mail: islee@konkuk.ac.kr

Tel: +82-2-450-4213, Fax: +82-2-3436-5432 
Table 1. Antiviral therapeutic candidates targeting EBV replication

\begin{tabular}{|c|c|c|c|c|}
\hline Target & Structure & Drug (prodrug) & Mode of action & References \\
\hline \multirow[t]{8}{*}{ EBV DNA Pol } & Acyclic nucleoside or & Acyclovir (valaciclovir) & Competitive substrates or & (Purifoy et al., 1993) \\
\hline & nucleotide analogue & Ganciclovir (valganciclovir) & DNA chain terminator & (Jung and Dorr, 1999) \\
\hline & & Penciclovir (famiciclovir) & & (Boyd et al., 1986) \\
\hline & & Adefovir & & (Friedrichs et al., 2004) \\
\hline & & Cidofovir & & (Friedrichs et al., 2004) \\
\hline & Pyrophosphate analogue & $\begin{array}{l}\text { Foscarnet, a phosphono- } \\
\text { formic acid }\end{array}$ & $\begin{array}{l}\text { Pyrophosphate-binding } \\
\text { site }\end{array}$ & $\begin{array}{l}\text { (Datta and Hood, 1981) } \\
\text { (Yajima et al., 1976) }\end{array}$ \\
\hline & & Phosphonoacetic acid & & \\
\hline & Non-nucleoside & 4-oxo-dihydroquinolines & V823 of EBV DNA Pol & (Hartline et al., 2005) \\
\hline \multirow{5}{*}{$\begin{array}{l}\text { Molecules except for } \\
\text { EBV DNA Pol }\end{array}$} & L-ribonucleoside & Maribavir & EBV ED-A & (Gershburg et al., 2004) \\
\hline & & & & (Zacny et al., 1999) \\
\hline & & & & $\begin{array}{l}\text { (Gershburg and Pagano, } \\
\text { 2002) }\end{array}$ \\
\hline & L-nucleoside & $\beta$-L-5-indodioxolane uracil & nk & (Kira et al., 2000) \\
\hline & & Indolocarbazole (NGIC-1) & nk & (Gershburg et al., 2004) \\
\hline
\end{tabular}

Pol: polymerase, V823: valine at amino acid position 823, PK: protein kinase, nk: not known.

\section{EBV INFECTION AND ANTIVIRAL DRUGS}

EBV, a human $\gamma$ herpes virus, is widely spread in human populations, and more than $95 \%$ of adults are EBV seropositive (Young and Rickinson, 2004). Primary EBV infection is usually asymptomatic in childhood, but the infection in adolescence frequently results in infectious mononucleosis (IM), and is associated with a variety of human malignancies including Burkitt's lymphoma, nasopharyngeal carcinoma, post-transplant lymphoproliferative disease, as well as HL (Rowe et al., 1986; Rickinson et al., 1987; Izumi and Kieff, 1997; Timms et al., 2003).

For the treatment of acute EBV infection, many antiviral drugs have been suggested as potent therapeutic candidates, all of which inhibit EBV replication. From a target perspective, they fall into two groups (Table 1). The first group includes acyclic nucleoside/nucleotide analogues and pyrophosphate analogues, the target of which is the EBV DNA polymerase. Despite their efficient inhibition of the viral polymerase in vitro in tissue culture experiments, they have displayed limitations by toxic side effects, poor oral bioavailability, and emergence of drug-resistant virus strains in in vivo treatment (Pagano et al., 1983; Purifoy et al., 1993). Recently, through further searching for new therapeutic compounds with the enhanced specificity in their antiviral action, a second group demonstrating unique modes of action has become available, which contains compounds of a mixed nature with divergent structures. Among them, maribavir inhibits phosphorylation of the EBV DNAprocessivity factor, EA-D indirectly by an EBV protein kinase, BGLF4. Despite yet unspecified modes of action in many cases, the common feature of this group is that their targets are located at molecules other than EBV DNA polymerase itself. However, in all cases, these anti-EBV drugs targeting the virus's own replication process have limited use in the majority of EBV-associated malignancies, in which EBV viruses are latently infected, because those drugs can function only when EBV replicates actively (van der Horst et al., 1991). In this respect, it is noteworthy that several groups have focused on the development of a potential method to induce a switch from latent to lytic infection with the subsequent treatment of those anti-EBV drugs as an option for the therapy of EBV-positive malignancies (Westphal et al., 2000; Daigle et al., 2011).

\section{EBV LATENCY AND HL}

During primary infection, EBV is transmitted by acutely infecting $B$ cells in the oropharyngeal epithelium. This process results in a localized replicative infection through lytic cycles, some of which undergo latency by permanent infection of circulating B cells. Most EBV associated malignancies including $\mathrm{HL}$ are characterized by such viral latency, in which viral genomes are replicated by host DNA polymerase only when cells divide, and propagate into progeny cells indefinitely. Therefore, the antiviral drugs aimed at viral replication processes listed in Table 1 would not affect EBV in the latent phase, as demonstrated by their lack of effect on latently EBV-infected cell lines or tumors (Pagano, 1995). This fact subsequently emphasizes the needs of special strategies for EBV-associated tumors distinct from those for the acute infection.

In latent infection, viral gene expression is tightly regulated with expression of only a limited number of EBV latency genes. Thus, only 12 genes of EBV can be expressed in different combinations during latent viral infection whereas about 70 major open reading frames are expressed during the lytic cycle (Kieff, 1996). The EBV latency genes are expressed in 4 programs: latency 0, I, II and III (Shah and Young, 2009). In latency III, all of the 12 latency genes are expressed, including 6 nuclear proteins (EBNA 1, 2, LP, 3A, 3B, 3C), 3 membrane proteins (LMP-1, LMP-2A and LMP-2B), BART, and 2 small RNAs (EBER 1 and 2). In latency II, the viral genes for EBNA-1, the three membrane proteins, and the EBERs are expressed while in latency state $0 /$, none or only EBNA-1 is expressed. B-lymphocytes in latency III are proliferating but highly immunogenic, while the remaining latency forms are seen in non-proliferating, resting cells. Among the 4 programs, 
$\mathrm{HL}$ has been reported to be closely associated with latency II, expressing only 6 viral genes: EBNA1, EBER1 and 2, LMP1, and LMP2A and 2B (Murray et al., 1992; Deacon et al., 1993; Grasser et al., 1994; Chiang et al., 1996).

According to its histopathological and clinical characteristics, $\mathrm{HL}$ is categorized into 2 types: $\mathrm{cHL}$, and the nodular lymphocyte predominance $\mathrm{HL}$ (NLPHL). About $95 \%$ of all $\mathrm{HL}$ cases represent $\mathrm{cHL}$, while the rest are NLPHL (Niedobitek et al., 1997). As described, one of the most unique features of $\mathrm{HL}$ is the rarity of malignant cells in the tumor mass. The two types of $\mathrm{HL}$ have their own unique malignant cells, designated as mononuclear Hodgkin's cells and multinucleated Reed-Sternberg (HRS) cells in cHL whereas they are called LP (lymphocyte predominant) cells in NLPHL, respectively (Poppema et al., 2008). Unlike the LP cells of NLPHL, EBV DNA genomes are frequently detected in HRS cells of $\mathrm{cHL}$ patients, in which the viruses display the type II form of latency expressing all of the type II-related 6 viral genes (Weiss et al., 1989; Weiss et al., 1999; Thomas et al., 2004; Kuppers, 2009). Since EBV is an oncogenic virus, this high association rate with EBV in HRS cells strongly suggests a possible role of EBV latent gene expression in the generation of the malignancies. Since the latent viral antigens are abundantly present in EBV-associated HRS cells, but not in the non-EBV-associated ones, providing extra targets for immunotherapy, the latent viral genes expressed in HRS cells and the related pathways have gained attention as additional therapeutic options in the case of EBV-associated cHL.

\section{THERAPEUTIC STRATEGIES AGAINST CHL}

Based on differences in histological features and cellular composition, $\mathrm{cHL}$ is further divided into 4 morphological subtypes (Pileri et al., 2002; Eberle et al., 2009): nodular sclerosis (NS) which accounts for the majority of cases, mixed cellularity (MC), lymphocyte-rich (LR), and lymphocyte-depleted (LD) $\mathrm{HL}$. LRHL and LDHL each comprises less than $5 \%$ of all $\mathrm{cHL}$ cases, and the majority is the NSHL subtype (Table 2). The detection rate of EBV in $\mathrm{cHL}$ varies depending on multifacto- rial etiological factors such as country, sex, ethnicity, and the age of patients. For example, EBV-positive cHL is less common in developed populations compared to underdeveloped countries $(20-50 \%$ in North American and European countries vs. $60-100 \%$ in Peru and Kenya) (Weiss et al., 1991; Herbst et al., 1992; Hummel et al., 1992; Chang et al., 1993; Weinreb et al., 1996). Among the subtypes of cHL, EBV genomes or proteins more commonly appear in the MC subtype with an increased incidence but less frequently in the other subtypes (Pallesen et al., 1991; Murray et al., 1992; Pinkus et al., 1994). Despite the complexity in its histological and cellular characteristics, the primary therapeutic strategies against the all subtypes in $\mathrm{cHL}$ cases are similar because the immunophenotypic and general features of the malignant cells of $\mathrm{cHL}$, the HRS cells, are surprisingly alike irrespective of the subtype or the presence of EBV.

With conventional chemotherapy, more than $80 \%$ of patients suffering from $\mathrm{cHL}$ are cured, which is otherwise a fatal disease with $90 \%$ of untreated patients dying within 2 to 3 years. However, up to $30 \%$ of patients with advanced $\mathrm{HL}$ will progress or relapse even after the therapeutic treatment (Connors et al., 2001); thus the development of new and more potent regimens with improved outcomes has become more necessary. In this respect, in addition to the general targets of HRS cells, the presence of EBV latent genes that are expressed in malignant cells provides an excellent opportunity for targeted therapy.

\section{Chemotherapy for early-stage cHL}

Regardless of its type, data of patients with early-stage HL show that present therapies result in high expectations of cure for $\mathrm{HL}$ patients, and more than $80 \%$ of patients have had their cancer successfully eradicated. Currently, treatment options of $\mathrm{HL}$ are tailored to type, stage, patient age, and an assessment of the risk of resistance (Diehl et al., 2003; Klimm et al., 2005). The induction chemotherapy regimens given as the initial treatment for $\mathrm{HL}$ are shown in Table 3. Although ABVD is the gold standard for all early HL cases, there are several data suggesting improved outcomes using the aggressive escalated BEACOPP regimen in advanced-stage $\mathrm{HL}$ (Carbone et al.,

Table 2. Epidemiology of Hodgkin lymphoma and their EBV association

\begin{tabular}{|c|c|c|c|c|c|}
\hline $\begin{array}{c}\text { REAL/WHO } \\
\text { classification } \\
(\% \text { cases/total } \mathrm{HL})\end{array}$ & Subtypes & Malignant cell & $\%$ cases of subtypes & $\begin{array}{c}\text { Association level with } \\
\qquad \mathrm{EBV}^{*}\end{array}$ & References \\
\hline \multirow[t]{6}{*}{$\mathrm{cHL}(95 \%)$} & & HRS cell & & Positive or negative & (Jarrett et al., 2005) \\
\hline & NSHL & & $60-80 \%$ of $\mathrm{cHL}$ & ++ & (Flavell et al., 2000) \\
\hline & $\mathrm{MCHL}$ & & $15-30 \%$ of $\mathrm{cHL}$ & +++ (up to $96 \%)$ & $\begin{array}{l}\text { (Herbst et al., 1992) } \\
\text { (Spitz et al., 1986) }\end{array}$ \\
\hline & & & & & (Cleary et al., 1994) \\
\hline & LDHL & & $<5 \%$ of $\mathrm{cHL}$ & ++ & (Slack et al., 2009) \\
\hline & LRHL & & $<5 \%$ of $\mathrm{cHL}$ & $+/-($ less than $10 \%)$ & $\begin{array}{l}\text { (Shimabukuro-Vorn- } \\
\text { hagen et al., 2005) }\end{array}$ \\
\hline NLPHL (5\%) & & LP cell & & Negative & (Chan, 1999) \\
\hline
\end{tabular}

REAL/WHO: Revised European American Lymphoma (REAL)/World Health Organization, EBV: Epstein-Barr virus; cHL, classical Hodgkin lymphoma, NLPHL: nodular lymphocyte-predominant Hodgkin lymphoma, NS: nodular sclerosis, MC: mixed cellularity, LD: Iymphocyte depletion, LR: lymphocyte-rich, HRS: Hodgkin/Reed-Sternberg, LP: lymphocyte predominant.

*varies depending on genetic and environmental factors of the affected patients. 
Table 3. Conventional combination chemotherapeutic strategies for $\mathrm{HL}$

\begin{tabular}{|c|c|c|c|}
\hline $\begin{array}{l}\text { Therapy } \\
\text { regimen }\end{array}$ & $\begin{array}{l}\text { Combination } \\
\text { of agents }\end{array}$ & Description & References \\
\hline MOPP & $\begin{array}{l}\text { Mechlorethamine } \\
\text { Vincristine } \\
\text { Procarbazine } \\
\text { Prednisone }\end{array}$ & $\begin{array}{l}\text { Developed in } 1964 . \\
\text { Derived by replacing methotrexate with } \\
\text { procarbazine in MOMP, the first } \\
\text { combination chemotherapy for } \mathrm{HL} \text {. }\end{array}$ & (Longo et al., 1986) \\
\hline ABVD & $\begin{array}{l}\text { Adriamycin [doxorubicin] } \\
\text { Bleomycin } \\
\text { Vinblastine } \\
\text { Dacarbazine }\end{array}$ & $\begin{array}{l}\text { Developed in the early } 1970 \text { 's as an } \\
\text { alternative to MOPP. } \\
\text { Currently is the standard chemotherapy } \\
\text { regimen for treating HL. }\end{array}$ & (Boleti and Mead, 2007) \\
\hline Stanford V & $\begin{array}{l}\text { Doxorubicin } \\
\text { Vinblastine } \\
\text { Mustard } \\
\text { Bleomycin } \\
\text { Vincristine } \\
\text { Etoposide } \\
\text { Prednisone }\end{array}$ & $\begin{array}{l}\text { Developed in } 1985 \text { at Stanford } \\
\text { University. } \\
\text { Characterized by frequent } \\
\text { administration over a shorter period of } \\
\text { time than the above regimens. }\end{array}$ & $\begin{array}{l}\text { (Hoppe et al., 1985; Hoppe et al., } \\
\text { 1989) }\end{array}$ \\
\hline BEACOPP & $\begin{array}{l}\text { Bleomycin } \\
\text { Etoposide } \\
\text { Doxorubicin } \\
\text { Cyclophosphamide } \\
\text { Vincristine } \\
\text { Procarbazine } \\
\text { Prednisone }\end{array}$ & $\begin{array}{l}\text { Developed in } 1997 \text { for advanced-stage } \\
\mathrm{HL}\end{array}$ & (Diehl et al., 1997) \\
\hline Escalated BEACOPP & $\begin{array}{l}\text { Higher doses of etopo } \\
\text { side and doxorubicin } \\
\text { and cyclophospha } \\
\text { mide and the addition } \\
\text { of granulocyte colony- } \\
\text { stimulating factor for } \\
\text { neutrophil support }\end{array}$ & $\begin{array}{l}\text { Modified to improve treatment results } \\
\text { with unfavorable and advanced-stage } \\
\text { HL. }\end{array}$ & $\begin{array}{l}\text { (Diehl et al., 1998a; Diehl et al., 1998b; } \\
\text { Engert et al., 2009) }\end{array}$ \\
\hline
\end{tabular}

2011). Although it has been reported that chemotherapy alone may be more efficient for controlling some disease cases (Meyer et al., 2004), combined-modality therapy is currently the most common treatment of $\mathrm{HL}$, which consists of an abbreviated course of chemotherapy and involved field radiation.

\section{Treatment strategies for the patients with relapsed $\mathrm{cHL}$}

Although most $\mathrm{HL}$ patients attain a remission after induction chemotherapy, relapse rates range from $10-15 \%$ in the early stage (Specht et al., 1998) to $30-40 \%$ in the advanced stage (Oza et al., 1993). For patients with relapsed HL, high dose chemotherapy plus autologous hematopoietic stem cell transplantation (HDC/HSCT) has become recognized as the most effective treatment. However, the fact that more than $15 \%$ of the relapsed patients are still dying of progressive lymphoma after HDC/HSCT treatment stresses an obvious need for more successful therapeutic strategies.

Currently, one of the most promising types of treatment for $\mathrm{HL}$ is immunotherapy targeting the malignant HRS cells of $\mathrm{cHL}$. Since HRS cells display virtually the same immunopathological characteristics among different HL subtypes, drug development in $\mathrm{HL}$ has been based on the general understanding of cellular pathways altered in HRS cells and of interactions between HRS cells and the tumor microenvironment (summarized in Fig. 1).

HRS cells: The most unique characteristic of HL compared to other tumors is the presence of a small number of malignant HRS cells in a background of non-neoplastic reactive lymphoid cell population. Although the origin of the HRS cells had been an issue of intense debate due to no obvious normal cellular counterpart to the phenotype of HRS cells, the presence of non-functional somatic mutations in rearranged immunoglobulin genes of HRS cells confirmed that they originate from preapoptotic B cells that lost the capacity to express a high-affinity B-cell receptor, which were then rescued from apoptosis by transforming events (Kuppers et al., 1994; Kuppers, 2003). To date, many cases of aberrant activation of signaling pathways and transcription factors involved in the rescue of HRS cells from apoptosis have been identified, knowledge from which has been applied to the development of novel therapeutic agents for relapsed $\mathrm{HL}$ after primary treatment.

Studies on signaling pathways of HRS cells have implicated deregulated activation of a variety of intercellular proteins (NF-kB, Jak/STATs, Akt/mTOR, Notch-1, and ERK) as well as surface receptors (CD30 and CD40) (Clodi and Younes, 1997; Fiumara et al., 2001; Younes et al., 2003; Zheng et al., 2003), 


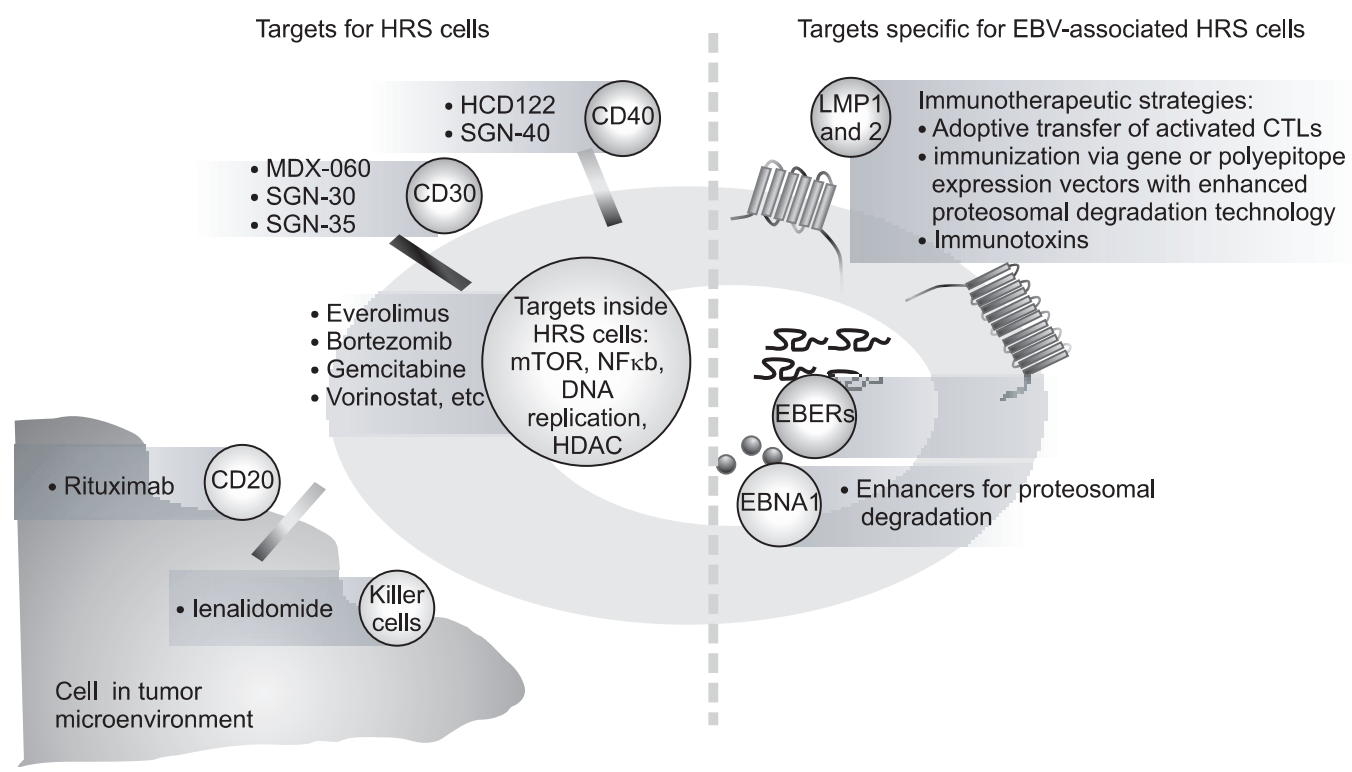

Fig. 1. Current and future therapeutic targets for HRS cells. A number of clinical trial targets for HRS cells have been identified and several novel treatments for $\mathrm{HL}$ therapy are under investigation. Many current approaches to handle relapsed $\mathrm{HL}$ aim to control specific target molecules that are related to the survival of HRS cells. In this respect, viral specific antigens expressed from EBV, a possible etiological agent for malignant HRS cells, are very attractive targets for development of a novel therapy. On the left of the figure are illustrated general targets for HRS cells, irrespective of the presence of EBV, with their related therapeutic options. On the right are targets specific for EBV-associated HRS cells. Targets expressed on the cells in tumor microenvironment are shown on the bottom left side. Gray circles and lightly shaded text boxes denote targets and their responding therapeutic option partners, respectively.

which are highly associated with pro-survival signals. Each of these proteins can be a therapeutic target of selective small molecule inhibitors. The AKT/mTOR pathway is an intracellular signaling pathway associated with the apoptotic process. In many malignant cells, this pathway is overactivated, and upon blockage of the pathway, cell cycle arrest and apoptosis of the cells subsequently take place. A preclinical study demonstrated that inhibition of mTOR, the mammalian target of rapamycin, caused apoptosis in HL cells. In addition, everolimus, a rapamycin-derived mTOR inhibitor, verified antitumor activity in relapsed $\mathrm{HL}$ patients in the phase I clinical study (Jundt et al., 2005; Yee et al., 2006), suggesting mTOR inhibitors as excellent therapeutic candidates for HL. Since NF- $\mathrm{kB}$ plays a central role in the regulation of various gene expression involved in cell survival, apoptosis, carcinogenesis, and inflammation, this molecule has been regarded as a very potential therapeutic target for many cancers (Baud and Karin, 2009). Bortezomib, a tripeptide with pyrazinoic acid, phenylalanine, and leucine with boronic acid, is a proteasome inhibitor that hinders activation of NF- $\kappa B$ by inhibiting cytoplasmic $I_{\kappa} B \alpha$ degradation (O'Connor, 2005). In preclinical studies, it inhibited proliferation of $\mathrm{HL}$ cell lines, and induced cell cycle arrest as well as apoptosis (Adams, 2003; Zheng et al., 2004). Not only the intracellular proteins described above but also surface receptor molecules can be specific targets for HL therapy. HRS cells characteristically express high levels of CD30

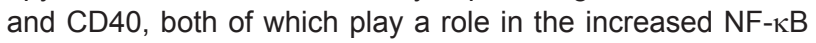
activity observed in $\mathrm{HL}$ as a member of the TNF receptor family. Immunotherapeutic agents targeting CD30 and CD40 are currently being evaluated for potential use in $\mathrm{HL}$. Since they are surface receptor antigens that contain extracellular moieties, various monoclonal antibodies (mAbs) and mAb-drug conjugates are easily accessible to their target molecules.
Initially, unconjugated mAbs targeting CD30 (MDX-060 and $\mathrm{SGN}-30)$ were evaluated in relapsed $\mathrm{HL}$ clinical cases. The antibodies failed to show efficient antitumor activity (Ansell et al., 2007; Forero-Torres et al., 2009; Blum et al., 2010), but a next-generation drug-antibody conjugate, SGN-35 (brentuximab vedotin), improved the modest clinical activity of the unconjugated mAbs. This potent immunotoxin contains the antitubulin agent monomethyl auristatin E attached to SGN-30 (Oflazoglu et al., 2008). The mAb-drug conjugate is rapidly internalized on CD30 binding. Recently, the U.S. Food and Drug Administration granted fast-track designation for SGN-35 for the treatment of HL. In case of anti-CD40 mAbs, HCD122 and SGN-40 had been evaluated in patients with CD40-expressing lymphoid malignancies (Law et al., 2005; Luqman et al., 2008; Robak, 2008; Younes, 2009).

In addition to the drugs acting on specific target molecules, anticancer drugs that broadly inhibit the signaling pathways activated in HRS cells are often used for patients with refractory HL. These wide-ranging inhibitors, such as systemic chemotherapeutic drugs, histone deacetylase (HDAC) inhibitors, and proteasome inhibitors, can modulate several unrelated signaling molecules (Bolden et al., 2006; Brogdon et al., 2007; Gediya et al., 2008; Tarasenko et al., 2008). Most systemic chemotherapeutic drugs with antitumor activity are DNA replication inhibitors. For patients with relapsed $\mathrm{HL}$, systemic chemotherapeutic drugs, such as gemcitabine (a nucleoside analog), vinblastine (an anti-microtubule drug), fludarabine (a purine analogue), and melphalan (an alkylating agent) have been used as a single agent or in combination regimens (Friedberg et al., 2003; Straus et al., 2011).

HDACs in cooperation with histone acetyltransferases (HATs) play an important role in epigenetic regulation of broad gene expression via post-transcriptional modification of his- 
tone proteins. The balance between the two enzymes is critical for regulating the expression and the functional status of a variety of proteins that are involved in cell proliferation, survival, and immunity (Glozak et al., 2005; Bolden et al., 2006; Brogdon et al., 2007). Unbalanced activities between HDAC and HAT have been reported in several malignancies, including HL (Glozak et al., 2005), implying HDAC inhibitors as a potential therapeutic target for HL. HDAC inhibitors, such as vorinostat (a suberoylanilide hydroxamic acid), mocetinostat (a benzamide), panobinostat (a hydroxamic acid), entinostat (a benzamide), are currently under phase I or II trials for relapsed HL (Dickinson et al., 2009; Boumber et al., 2011; Jona et al., 2011; Kirschbaum et al., 2011).

Tumor microenvironment in $\mathrm{HL}$ : The nature of the aberrant immune response in the vicinity of HRS cells is very unique. Pathologic examination of infiltrating cells around HRS cells demonstrated that CD4 T cells, eosinophils, B cells, and macrophages, are abundantly present favorably producing $\mathrm{TH} 2$ and immunosuppressive chemokines/cytokines, whereas CD8 T cells and NK cells are generally sparse. This tumor microenvironment plays a significant role in the maintenance of ineffective immunity against HRS cells (Poppema et al., 1999;
Lamprecht et al., 2008; Aldinucci et al., 2010), providing a favorable milieu for HRS cells to proliferate and escape from apoptosis and host antitumor defenses.

Therapeutic strategies targeting the tumor microenvironment had been evaluated by targeting CD20 in healthy B cells using rituximab (Coiffier et al., 1998), an anti-CD20 mAb, in patients with relapsed HL. CD20 is highly expressed on reactive $B$ cells present in the tumor infiltrates whereas its surface expression on HRS cells is very low (Foss et al., 1999). The treatment of rituximab eliminates CD20-positive reactive $B$ cells that are supportive to HRS cells, subsequently depriving the malignant cells of survival signals. Promising results in relapsed $\mathrm{cHL}$ therapy have been reported in clinical trials testing rituximab (Oki and Younes, 2010).

Another potential therapeutic agent targeting the tumor microenvironment of $\mathrm{HL}$ is lenalidomide, a thalidomide-derivative. Lenalidomide functions at multiple steps, including direct induction of apoptosis in tumor cells as well as activation of killer cells (Bartlett et al., 2004). An international phase I/II study with lenalidomide for elderly HL patients had been initiated (Boll et al., 2010).

Table 4. Functions of six EBV genes expressed in HRS cells

\begin{tabular}{|c|c|c|c|}
\hline $\begin{array}{l}\text { EBV genes } \\
\text { expressed } \\
\text { in HRS cells }\end{array}$ & Functions (target cellular proteins) & Therapeutic strategies & References \\
\hline EBER 1 and 2 & $\begin{array}{l}\text { Cell growth (IGF-1, IL-6, IL-9) } \\
\text { Modulation of immune response } \\
\text { (IL-10, TLR3, RIG-1) } \\
\text { Inhibition of apoptosis (PKR) }\end{array}$ & $\mathrm{Nt}$ & $\begin{array}{l}\text { (Ho et al., 1999; Komano et al., } \\
\text { 1999; Kitagawa et al., 2000; } \\
\text { Yamamoto et al.., 2000; Iwakiri } \\
\text { et al., 2003; Iwakiri et al., 2005; } \\
\text { Samanta et al., 2006; Samanta et } \\
\text { al., 2008; Iwakiri et al., 2009; Iwakiri } \\
\text { and Takada, 2010) }\end{array}$ \\
\hline EBNA1 & $\begin{array}{l}\text { Modulation of EBV DNA replication } \\
\text { Maintenance of EBV episome } \\
\text { Inhibition of apoptosis (survivin) }\end{array}$ & $\begin{array}{l}\text { Enhanced proteosomal degradation } \\
\text { (enhancement of immunogenicity) }\end{array}$ & (Tellam et al., 2001) \\
\hline LMP1 & $\begin{array}{l}\text { Inhibition of apoptosis (NF-kB, PI3K/ } \\
\text { Akt/mTOR, Jak/STAT) } \\
\text { Immunesuppressor (IL-10) }\end{array}$ & $\begin{array}{l}\text { Enhanced proteosomal degradation } \\
\text { (enhancement of immunogenicity, } \\
\text { and rescue from oncogenic } \\
\text { phenotypes) } \\
\text { Adoptive immunotherapy (transfer } \\
\text { of LMP1-specific CTLs, or primed } \\
\text { DCs) } \\
\text { Immunization with LMP1 gene or } \\
\text { polyepitope expression vectors }\end{array}$ & $\begin{array}{l}\text { (Duraiswamy et al., 2003; Tellam et } \\
\text { al., 2003; Taylor et al., 2004; Smith } \\
\text { et al., 2006; Pan et al., 2009; } \\
\text { Lutzky et al., 2010; Chia et al., } \\
\text { 2011) }\end{array}$ \\
\hline LMP2A & $\begin{array}{l}\text { Prosurvival signal (Ras/PI3K/Akt, } \\
\text { Notch and } \beta \text {-catenin/Wnt) } \\
\text { Modulation of innate immune } \\
\text { response }\end{array}$ & $\begin{array}{l}\text { Adoptive immunotherapy (transfer } \\
\text { of LMP2A-specific CTLs, or primed } \\
\text { DCs) } \\
\text { Immunization with LMP2A gene or } \\
\text { polyepitope expression vectors }\end{array}$ & $\begin{array}{l}\text { (Taylor et al., 2004; Smith et al., } \\
\text { 2006; Pan et al., 2009; Shah et al., } \\
\text { 2009; Lutzky et al., 2010; Chia et } \\
\text { al., 2011) }\end{array}$ \\
\hline LMP2B & $\begin{array}{l}\text { Modulation of innate immune } \\
\text { response }\end{array}$ & nt & (Shah et al., 2009) \\
\hline
\end{tabular}

TLR: Toll-like receptor, RIG: retinoic acid-inducible gene, PKR: RNA-dependent protein kinase, Nt: not tested, CTL: cytotoxic T lymphocyte, DC: dendritic cells. 


\section{Treatment strategies for the patients with EBV-associated cHL}

The incidence of high relapse rates in EBV-associated HL compared to non-EBV-associated $\mathrm{HL}$ after primary treatment is still conflicting. However, in population-based studies have consistently shown a noticeable survival disadvantage in EBVpositive HL especially in the case of older patients (Enblad et al., 1999; Clarke et al., 2001; Stark et al., 2002), indicating the influence of EBV existence in HRS cells on clinical outcome. Furthermore, the fact that an EBV transforming protein, LMP1, is expressed almost $100 \%$ in HRS cells of HL in HIV-infected patients suggests that EBV may play as a crucial etiological agent in the generation of HRS cells, at least in certain circumstances (Thompson et al., 2004; Carbone et al., 2009).

EBV infection in HRS cells exhibits the pattern of the type II latency, expressing only a limited number of viral genes: EBERs, EBNA1, LMP1, LMP2A and 2B. Thus, the viral genes expressed during the type II latency are hypothetically the most excellent candidates for the therapeutic target against the malignant HRS cells of HL (Table 4).

EBERs: EBV-encoded small RNA 1 and 2 (EBER1 and EBER2) are nonpolyadenylated and noncoding RNAs of 167 and 172 nucleotides, respectively (Rosa et al., 1981). They form stem-loop double-stranded RNA (dsRNA) structures by intermolecular base-pairing, which enable them to interact with several cellular proteins (Ho et al., 1999). It has been demonstrated that EBERs play a role in EBV-mediated oncogenesis in EBV latently-infected cells. First, EBERs affect membrane signaling by initiating the production of various interleukins (ILs) that are involved in cell growth, such as IL-6, IL-9, or insulin-like growth factor-1 (Ho et al., 1999; Kitagawa et al., 2000; Iwakiri et al., 2003; Iwakiri et al., 2005). They also play a role in regulation of apoptosis by binding the RNA-dependent protein kinase (PKR), subsequently inhibiting PKRmediated apoptosis in the EBV infected cells (Komano et al., 1999; Yamamoto et al., 2000). In addition, EBERs can modulate interferon (IFN)/antiviral response. It was demonstrated that EBERs induce expression of type-I IFNs by binding to the retinoic acid-inducible gene I (RIG-I) product that is a cytosolic protein that recognizes viral dsRNA inside the cell (Samanta et al., 2006). Another evidence of a role of EBERs in innate immunity is their binding to Toll-like receptor 3 after secreted from EBV-infected cells (Iwakiri et al., 2009; Iwakiri and Takada, 2010), triggering innate immunity that might explain immunopathologic diseases caused by active EBV infection. However, EBERs also induce an anti-inflammatory cytokine, IL-10, through RIG-1-mediated interferon regulatory factor (IRF) 3 (Samanta et al., 2008), suggesting that modulation of innate immune signaling by EBERs may contribute to EBVmediated oncogenesis.

In all types of EBV-associated cancers, EBERs are abundantly expressed (Forte and Luftig, 2011). This fact makes EBERs a potentially important target for novel therapies for EBV-associated cancers including HL. However, other studies have found that EBERs are not essential for primary infection, viral replication, or B-cell immortalization (Swaminathan et al., 1991). Furthermore, deletion of EBERs showed little effect on the EBV transformation frequency of primary $B$ cells (Gregorovic et al., 2011). Thus, to develop novel therapeutic approaches to EBV-associated cancers based on their EBER expression, clear mechanisms of EBERs should be identified by further studies.
EBNA1: EBNA1 is an indispensable protein for viral DNA replication and maintenance of the viral episome in infected cells (Hsieh et al., 1993). It has been shown that EBNA1 not only promotes the efficiency of immortalization of human primary B cells in vivo, but also inhibits apoptosis by up-regulating the apoptosis suppressor protein, survivin (Humme et al., 2003; Lu et al., 2011), suggesting that it may play a direct role in the pathogenesis of EBV-associated malignancies.

Since EBNA1 is consistently expressed not only in chronic active EBV infection, but also in all EBV-associated malignancies (Yoshioka et al., 2003), the viral antigen has been suggested as a very potent target for immunotherapy against HL. However, it is not easy to detect EBNA1-specific cytotoxic T lymphocytes (CTLs) from blood taken during primary infection or from healthy virus carriers (Masucci et al., 1992; Rickinson et al., 1992; Steven et al., 1996), because EBNA1 is protected from processing and presentation via the MHC class I pathway due to its internal Glycine-Alanine repeat (GAr) domain (Levitskaya et al., 1995), which acts as a inhibitory signal to prevent proteasome dependent degradation of this antigen (Levitskaya et al., 1997). Nevertheless EBNA1 is a very attractive viral antigen for a therapeutic target due to its ubiquitous presence in all EBV infected cells, and novel strategies to avoid the restricted class I processing of EBNA1 have been reported by several groups. In the experiment of Tellam and his collegues, the EBNA1 gene was covalently linked with ubiquitin, and subject to targeting to the $\mathrm{N}$-end rule pathway, in which the stability level of a protein in vivo can be dramatically changed by the identity of its $\mathrm{N}$-terminal residue (Varshavsky, 1996; Tobery and Siliciano, 1999; Dantuma et al., 2000). These modifications dramatically enhanced intracellular degradation of the protein and restored CD8+ $T$ cell recognition, demonstrating that GAr-mediated proteosomal blockade on EBNA1 can be reversed (Tellam et al., 2001). Moreover, it was demonstrated that CD8 T cells from patients with $\mathrm{HL}$ were successfully stimulated in vitro with a construct containing a GAr-deleted EBNA1, reversing the functional T cell impairment as well as responding to tumor cells expressing EBNA1 (Smith et al., 2006).

Currently, it is not easy to discover a therapeutic drug that specifically modulates the degradation of EBNA1. However, if fine pharmacologic manipulation of the ubiquitin proteasome system that could alter the outcome of many diseases become possible, one might be able to develop highly specific drugs that target the degradation pathways of a single or a few proteins with no side effect on other proteins (Reinstein and Ciechanover, 2006).

EBV-encoded latent membrane proteins, LMP1, LMP2A, and 2B: LMP1 acts as a constitutively active receptor in a ligand-independent manner, mimicking CD40 (Gires et al., 1997). It activates the majority of signaling pathways that are known to be activated in HRS cells, including NF-kB, PI3K/ Akt/mTOR, and Jak/STAT pathways, thereby induces various antiapoptotic proteins and cytokines (Chen et al., 2003; Lambert and Martinez, 2007; Kung et al., 2011). Since normal germinal center B cells that lack BCR in their cell surfaces are eliminated by apoptosis, the HRS precursor cell is assumed to be rescued by LMP1 that plays a critical role in the protection of B cells from apoptotic death by up-regulating several antiapoptosis genes (Asso-Bonnet et al., 1998; Lee et al., 2003).

The LMP2 gene encodes two protein isoforms, LMP2A and LMP2B. They are identical except for an additional 119 aa- 
long cytoplasmic region at the amino-terminus of the LMP2A isoform (Longnecker and Kieff, 1990). LMP2A mimics BCR, thereby provides an essential prosurvival signal for $B$ cells. In EBV-infected B cells, LMP2A functions to promote viral latency, providing signals to ensure cell survival in the absence of BCR signaling (Longnecker, 2000). It can enhance cell growth, survival, and cellular differentiation through activation of the Ras/PI3K/Akt, Notch and $\beta$-catenin/Wnt signaling pathways (Scholle et al., 2000; Morrison et al., 2003; Anderson and Longnecker, 2008). Compared to LMP2A, the role of LMP2B are relatively unknown. Recently, it was reported that LMP2B as well as LMP2A modulate signaling from receptors involved in innate immune responses (Shah et al., 2009). Overall, the two viral proteins, LMP1 and LMP2A, are considered the major players in the generation of EBV-associated HRS phenotypes (Bechtel et al., 2005).

Use of mAbs as immunotoxins against the upregulated surface molecules of HRS cells, such as CD30 and CD40, for targeted immunotherapy was stated in the previous section. In order to function as a potent target molecule against immunotoxins, the presence of an extracellular domain and its easy accessibility are essential, which are lacking in LMP1 as well as LMP2A (Flanagan et al., 2003). These LMPs contain relatively large cytoplasmic domains with extremely short extracellular loops connecting transmembrane segments, which are not easily accessible by antibodies (Gires et al., 1997; Panousis and Rowe, 1997; Lynch et al., 2002). Moreover, the extracellular loop regions marginally elicit antibodies in the course of natural infection and tumorigenesis (Paramita et al., 2011). Thus, despite their abundance, antibody-based targeting of LMP1 or LMP2 on EBV-positive HRS cells has low therapeutic possibilities.

Recently, it was shown that conformational peptides mimicking two adjacent loops of LMP1 induce high-affinity antibodies with antitumor activities in mice (Delbende et al., 2009). However, unlike the in vivo experimental animal settings, the induction of effective CTL responses against those proteins has showed difficulties per se due to unique characteristics of HRS cells and their microenvironment as described (Marshall et al., 2003). For example, in vitro HRS cells that present epitopes from LMP1 and LMP2A are subject to lysis by EBV-specific CTLs, but EBV-infected HRS cells survive in vivo (Sing et al., 1997; Chapman et al., 2001; Su et al., 2001). Thus, although EBV-associated HL patients initially achieve an effective anti-EBV response after the period of first EBV infection, they do not completely eradicate EBV-infected HRS cells. In addition, despite the presence of EBV-specific CTLs in the peripheral blood, the CTLs are not found in the immediate surrounding area of EBV-positive HRS cells (Frisan et al., 1995). Thus, for successful CTL therapy for EBV-positive HL, not only effective EBV-specific CTLs, but possibly also the modulation of the tumor microenvironment to eliminate the barriers that inhibit CTL function will be required.

Nevertheless, these LMP molecules still draw attention as major targets for therapeutic purposes. Since patients with $\mathrm{HL}$ display functional impairment of CTL, adoptive cellular immunotherapy based on efficient EBV-specific CTL cells may provide an answer to success. Development of an epitope-based vaccination strategy to augment EBV-specific cytolytic activity of CTLs is currently paid attention to as one of the preferred approaches for the treatment of EBV-associated relapsed $\mathrm{HL}$. Firstly, efficient antigen (epitope) presentation by antigen pre- senting cells may improve the CTL activities. The therapeutic potentials of dendritic cell (DC) vaccine transduced by a recombinant vaccinia or adeno-associated virus carrying LMP1 and LMP2 CTL epitope DNA were evaluated, and the treatment of the vaccine was effective on eliminating tumors of syngeneic animals (Taylor et al., 2004; Pan et al., 2009). And a phase II study on vaccination of autologous DCs transduced with an adenovirus encoding a truncated LMP1 and full-length LMP2 is under evaluation for the safety and efficacy for patients with metastatic EBV-positive nasopharyngeal carcinoma (Lutzky et al., 2010; Chia et al., 2011). In this case, the truncated form of LMP1 was utilized because the full-length protein has both oncogenic and immunosuppressive properties (Gottschalk et al., 2003). Secondly, antigen presentation by polyepitope vaccines may enhance CTL activities. A polyepitope comprises at least one recombinant protein including multiple CTL epitopes from one or more pathogens. A recombinant poxvirus vaccine encoding a polyepitope derived from LMP1, called as an LMP1 polyepitope vaccine, displayed stronger anti-LMP1 responses (Duraiswamy et al., 2003). In addition, an exposure to a replication-deficient adenoviral system with polyepitopes from LMP1 or LMP2 induced effective expanding of specific $T$ cells. HL patients with this adenoviral construct in combination with IL-2, were sufficient to reverse the functional $\mathrm{T}$ cell impairment and restored cytolytic function (Smith et al., 2006). Like EBNA1, LMP1 molecules can be efficiently presented via cotranslational ubiquitination combined with $\mathrm{N}$-end rule targeting. Since this method is involved with enhanced degradation of LMP1, this strategy completely abrogates cellular signaling pathways associated with the oncogenic phenotype, and helps in enhancing immunogenicity (Tellam et al., 2003), suggesting that the proteasomal targeting strategy could be therapeutically utilized for various tumor-associated oncogenes.

\section{CONCLUSIONS}

In the early twentieth century, $\mathrm{cHL}$ was incurable in most cases. Although $\mathrm{cHL}$ is currently considered one of the most curable forms of cancer with conventional chemotherapy, therapeutic challenges still remain, especially in finding novel strategies to control patients with relapsed $\mathrm{cHL}$, albeit in small numbers. Since immunopathogenic features of HRS cells are very similar in both EBV-positive $\mathrm{cHL}$ and EBV-negative $\mathrm{cHL}$, efforts to find cellular targets for drug development to treat $\mathrm{CHL}$ have been mainly focused on common phenotypes of HRS cells regardless of the presence of EBV. However, the presence of EBV-latent antigens abundantly expressed in the malignant HRS cells represents an attractive therapeutic option for targeted immunotherapy. Through continued researches of existing and new treatment options for $\mathrm{cHL}$, advances should continue to be made.

\section{ACKNOWLEDGMENTS}

This paper was supported by Konkuk University in 2008.

\section{REFERENCES}

Adams, J. (2003) Potential for proteasome inhibition in the treatment of 
cancer. Drug Discov. Today 8, 307-315.

Aldinucci, D., Gloghini, A., Pinto, A., De Filippi, R. and Carbone, A (2010) The classical Hodgkin's lymphoma microenvironment and its role in promoting tumour growth and immune escape. J. Pathol. 221, 248-263.

Ambinder, R. F., Browning, P. J., Lorenzana, I., Leventhal, B. G., Cosenza, H., Mann, R. B., MacMahon, E. M., Medina, R., Cardona, V., Grufferman, S. and et al. (1993) Epstein-Barr virus and childhood Hodgkin's disease in Honduras and the United States. Blood 81, 462-467.

Anderson, L. J. and Longnecker, R. (2008) An auto-regulatory loop for EBV LMP2A involves activation of Notch. Virology 371, 257-266.

Ansell, S. M., Horwitz, S. M., Engert, A., Khan, K. D., Lin, T., Strair, R. Keler, T., Graziano, R., Blanset, D., Yellin, M., Fischkoff, S., Assad, A. and Borchmann, P. (2007) Phase I/II study of an anti-CD30 monoclonal antibody (MDX-060) in Hodgkin's lymphoma and anaplastic large-cell lymphoma. J. Clin. Oncol. 25, 2764-2769.

Asso-Bonnet, M., Feuillard, J., Ferreira, V., Bissieres, P., Tarantino, N., Korner, M. and Raphael, M. (1998) Relationship between IkappaBalpha constitutive expression, TNFalpha synthesis, and apoptosis in EBV-infected lymphoblastoid cells. Oncogene 17, 16071615.

Bartlett, J. B., Dredge, K. and Dalgleish, A. G. (2004) The evolution of thalidomide and its IMiD derivatives as anticancer agents. Nat Rev. Cancer 4, 314-322.

Baud, V. and Karin, M. (2009) Is NF-kappaB a good target for cancer therapy? Hopes and pitfalls. Nat. Rev. Drug Discov. 8, 33-40.

Bechtel, D., Kurth, J., Unkel, C. and Kuppers, R. (2005) Transformation of BCR-deficient germinal-center B cells by EBV supports a major role of the virus in the pathogenesis of Hodgkin and posttransplantation lymphomas. Blood 106, 4345-4350.

Blum, K. A., Jung, S. H., Johnson, J. L., Lin, T. S., Hsi, E. D., Lucas D. M., Byrd, J. C., Cheson, B. D. and Bartlett, N. L. (2010) Serious pulmonary toxicity in patients with Hodgkin's lymphoma with SGN30 , gemcitabine, vinorelbine, and liposomal doxorubicin is associated with an FcgammaRIIla-158 V/F polymorphism. Ann. Oncol. 21, 2246-2254.

Bolden, J. E., Peart, M. J. and Johnstone, R. W. (2006) Anticancer activities of histone deacetylase inhibitors. Nat. Rev. Drug Discov. 5, 769-784.

Boleti, E. and Mead, G. M. (2007) ABVD for Hodgkin's lymphoma: full-dose chemotherapy without dose reductions or growth factors. Ann. Oncol. 18, 376-380.

Boll, B., Borchmann, P., Topp, M.S., Hanel, M., Reiners, K. S., Engert, A. and Naumann, R. (2010) Lenalidomide in patients with refractory or multiple relapsed Hodgkin lymphoma. Br. J. Haematol. 148 , 480-482.

Boumber, Y., Younes, A. and Garcia-Manero, G. (2011) Mocetinostat (MGCD0103): a review of an isotype-specific histone deacetylase inhibitor. Expert Opin. Investig. Drugs 20, 823-829.

Boyd, M. R., Cole, M., Harnden, M. R., Luk, K., Rush, M. A., Sutton, D. and Hodge, R. A. (1986) Improvement of the bioavailability of the anti-herpes virus agent BVDU by use of 5'-O-alkoxycarbonyl derivatives with increased metabolic stability. J. Antimicrob. Chemother. 18, 207-213.

Brink, A. A., Oudejans, J. J., Jiwa, M., Walboomers, J. M., Meijer, C. J. and van den Brule, A. J. (1997) Multiprimed cDNA synthesis followed by PCR is the most suitable method for Epstein-Barr virus transcript analysis in small lymphoma biopsies. Mol. Cell Probes 11, 39-47.

Brogdon, J. L., Xu, Y., Szabo, S. J., An, S., Buxton, F., Cohen, D. and Huang, Q. (2007) Histone deacetylase activities are required for innate immune cell control of Th1 but not Th2 effector cell function. Blood 109, 1123-1130.

Carbone, A., Gloghini, A., Serraino, D. and Spina, M. (2009) HIV-associated Hodgkin lymphoma. Curr. Opin. HIV AIDS 4, 3-10.

Carbone, A., Spina, M., Gloghini, A. and Tirelli, U. (2011) Classica Hodgkin's lymphoma arising in different host's conditions: pathobiology parameters, therapeutic options, and outcome. Am. J. Hematol. 86, 170-179.

Chan, W. C. (1999) Cellular origin of nodular lymphocyte-predominant Hodgkin's lymphoma: immunophenotypic and molecular studies.
Semin. Hematol. 36, 242-252

Chang, K. L., Albujar, P. F., Chen, Y. Y., Johnson, R. M. and Weiss, L. M. (1993) High prevalence of Epstein-Barr virus in the ReedSternberg cells of Hodgkin's disease occurring in Peru. Blood 81, 496-501.

Chapman, A. L., Rickinson, A. B., Thomas, W. A., Jarrett, R. F., Crocker, J. and Lee, S. P. (2001) Epstein-Barr virus-specific cytotoxic $\mathrm{T}$ lymphocyte responses in the blood and tumor site of Hodgkin's disease patients: implications for a T-cell-based therapy. Cancer Res. 61, 6219-6226.

Chen, H., Hutt-Fletcher, L., Cao, L. and Hayward, S. D. (2003) A positive autoregulatory loop of LMP1 expression and STAT activation in epithelial cells latently infected with Epstein-Barr virus. J. Virol. 77, 4139-4148.

Chia, W. K., Wang, W. W., Teo, M., Tai, W. M., Lim, W. T., Tan, E. H., Leong, S. S., Sun, L., Chen, J. J., Gottschalk, S. and Toh, H. C. (2011) A phase II study evaluating the safety and efficacy of an adenovirus-dLMP1-LMP2 transduced dendritic cell in patients with advanced metastatic nasopharyngeal carcinoma. Ann. Oncol. Aug 4. [Epub ahead of print]

Chiang, A. K., Tao, Q., Srivastava, G. and Ho, F. C. (1996) Nasal NKand T-cell lymphomas share the same type of Epstein-Barr virus latency as nasopharyngeal carcinoma and Hodgkin's disease. Int. J. Cancer 68, 285-290.

Clarke, C. A., Glaser, S. L., Dorfman, R. F., Mann, R., DiGiuseppe, J. A., Prehn, A. W. and Ambinder, R. F. (2001) Epstein-Barr virus and survival after Hodgkin disease in a population-based series of women. Cancer 91, 1579-1587.

Cleary, S. F., Link, M. P. and Donaldson, S. S. (1994) Hodgkin's disease in the very young. Int. J. Radiat. Oncol. Biol. Phys. 28, 77-83.

Clodi, K. and Younes, A. (1997) Reed-Sternberg cells and the TNF family of receptors/ligands. Leuk. Lymphoma 27, 195-205.

Coiffier, B., Haioun, C., Ketterer, N., Engert, A., Tilly, H., Ma, D., Johnson, P., Lister, A., Feuring-Buske, M., Radford, J. A., Capdeville, R., Diehl, V. and Reyes, F. (1998) Rituximab (anti-CD20 monoclonal antibody) for the treatment of patients with relapsing or refractory aggressive lymphoma: a multicenter phase II study. Blood $\mathbf{9 2}$, 1927-1932.

Connors, J. M., Noordijk, E. M. and Horning, S. J. (2001) Hodgkin's lymphoma: basing the treatment on the evidence. Hematology Am. Soc. Hematol. Educ. Program 178-193.

Daigle, D., Gradoville, L., Tuck, D., Schulz, V., Wang'ondu, R., Ye, J., Gorres, K. and Miller, G. (2011) Valproic acid antagonizes the capacity of other histone deacetylase inhibitors to activate the Epstein-barr virus lytic cycle. J. Virol. 85, 5628-5643.

Dantuma, N. P., Heessen, S., Lindsten, K., Jellne, M. and Masucci, M. G. (2000) Inhibition of proteasomal degradation by the gly-Ala repeat of Epstein-Barr virus is influenced by the length of the repeat and the strength of the degradation signal. Proc. Natl. Acad. Sci. USA 97, 8381-8385.

Datta, A. K. and Hood, R. E. (1981) Mechanism of inhibition of EpsteinBarr virus replication by phosphonoformic acid. Virology 114, 5259

Deacon, E. M., Pallesen, G., Niedobitek, G., Crocker, J., Brooks, L., Rickinson, A. B. and Young, L. S. (1993) Epstein-Barr virus and Hodgkin's disease: transcriptional analysis of virus latency in the malignant cells. J. Exp. Med. 177, 339-349.

Delbende, C., Verwaerde, C., Mougel, A. and Tranchand Bunel, D. (2009) Induction of therapeutic antibodies by vaccination against external loops of tumor-associated viral latent membrane protein. J. Virol. 83, 11734-11745.

Dickinson, M., Ritchie, D., DeAngelo, D. J., Spencer, A., Ottmann, O. G., Fischer, T., Bhalla, K. N., Liu, A., Parker, K., Scott, J. W., Bishton, M. and Prince, H. M. (2009) Preliminary evidence of disease response to the pan deacetylase inhibitor panobinostat (LBH589) in refractory Hodgkin Lymphoma. Br. J. Haematol. 147, 97-101.

Diehl, V., Franklin, J., Hasenclever, D., Tesch, H., Pfreundschuh, M., Lathan, B., Paulus, U., Sieber, M., Rueffer, J. U., Sextro, M., Engert, A., Wolf, J., Hermann, R., Holmer, L., Stappert-Jahn, U., Winnerlein-Trump, E., Wulf, G., Krause, S., Glunz, A., von Kalle, K., Bischoff, H., Haedicke, C., Duehmke, E., Georgii, A. and Loeffler, M. (1998a) BEACOPP, a new dose-escalated and accelerated 
regimen, is at least as effective as COPP/ABVD in patients with advanced-stage Hodgkin's lymphoma: interim report from a trial of the German Hodgkin's Lymphoma Study Group. J. Clin. Oncol. 16, 3810-3821.

Diehl, V., Franklin, J., Hasenclever, D., Tesch, H., Pfreundschuh, M., Lathan, B., Paulus, U., Sieber, M., Ruffer, J. U., Sextro, M., Engert, A., Wolf, J., Hermann, R., Holmer, L., Stappert-Jahn, U., Winnerlein-Trump, E., Wulf, G., Krause, S., Glunz, A., von Kalle, K., Bischoff, H., Haedicke, C., Duhmke, E., Georgii, A. and Loeffler, M. (1998b) BEACOPP: a new regimen for advanced Hodgkin's disease. German Hodgkin's Lymphoma Study Group. Ann. Oncol. 9, S67-71.

Diehl, V., Sieber, M., Ruffer, U., Lathan, B., Hasenclever, D., Pfreundschuh, M., Loeffler, M., Lieberz, D., Koch, P., Adler, M. and Tesch, H. (1997) BEACOPP: an intensified chemotherapy regimen in advanced Hodgkin's disease. The German Hodgkin's Lymphoma Study Group. Ann. Oncol. 8, 143-148.

Diehl, V., Stein, H., Hummel, M., Zollinger, R. and Connors, J. M. (2003) Hodgkin's lymphoma: biology and treatment strategies for primary, refractory, and relapsed disease. Hematology Am. Soc. Hematol. Educ. Program 225-247.

Duraiswamy, J., Sherritt, M., Thomson, S., Tellam, J., Cooper, L., Connolly, G., Bharadwaj, M. and Khanna, R. (2003) Therapeutic LMP1 polyepitope vaccine for EBV-associated Hodgkin disease and nasopharyngeal carcinoma. Blood 101, 3150-3156.

Eberle, F. C., Mani, H. and Jaffe, E. S. (2009) Histopathology of Hodgkin's lymphoma. Cancer J. 15, 129-137.

Enblad, G., Sandvej, K., Sundstrom, C., Pallesen, G. and Glimelius, B. (1999) Epstein-Barr virus distribution in Hodgkin's disease in an unselected Swedish population. Acta. Oncol. 38, 425-429.

Engert, A., Diehl, V., Franklin, J., Lohri, A., Dorken, B., Ludwig, W. D. Koch, P., Hanel, M., Pfreundschuh, M., Wilhelm, M., Trumper, L., Aulitzky, W. E., Bentz, M., Rummel, M., Sezer, O., Muller-Hermelink, H. K., Hasenclever, D. and Loffler, M. (2009) Escalated-dose BEACOPP in the treatment of patients with advanced-stage Hodgkin's lymphoma: 10 years of follow-up of the GHSG HD9 study. J. Clin. Oncol. 27, 4548-4554.

Fiumara, P., Snell, V., Li, Y., Mukhopadhyay, A., Younes, M., Gillenwater, A. M., Cabanillas, F., Aggarwal, B. B. and Younes, A. (2001) Functional expression of receptor activator of nuclear factor kappaB in Hodgkin disease cell lines. Blood 98, 2784-2790.

Flanagan, J., Middeldorp, J. and Sculley, T. (2003) Localization of the Epstein-Barr virus protein LMP 1 to exosomes. J. Gen. Virol. 84 1871-1879.

Flavell, K. J., Biddulph, J. P., Constandinou, C. M., Lowe, D., Scott, K., Crocker, J., Young, L. S. and Murray, P. G. (2000) Variation in the frequency of Epstein-Barr virus-associated Hodgkin's disease with age. Leukemia 14, 748-753.

Forero-Torres, A., Leonard, J. P., Younes, A., Rosenblatt, J. D., Brice, P., Bartlett, N. L., Bosly, A., Pinter-Brown, L., Kennedy, D., Sievers, E. L. and Gopal, A. K. (2009) A Phase II study of SGN-30 (antiCD30 mAb) in Hodgkin lymphoma or systemic anaplastic large cell lymphoma. Br. J. Haematol. 146, 171-179.

Forte, E. and Luftig, M. A. (2011) The role of microRNAs in EpsteinBarr virus latency and lytic reactivation. Microbes Infect. [Epub ahead of print]

Foss, H. D., Reusch, R., Demel, G., Lenz, G., Anagnostopoulos, I., Hummel, M. and Stein, H. (1999) Frequent expression of the Bcell-specific activator protein in Reed-Sternberg cells of classical Hodgkin's disease provides further evidence for its B-cell origin. Blood 94, 3108-3113.

Friedberg, J. W., Neuberg, D., Kim, H., Miyata, S., McCauley, M., Fisher, D. C., Takvorian, T. and Canellos, G. P. (2003) Gemcitabine added to doxorubicin, bleomycin, and vinblastine for the treatment of de novo Hodgkin disease: unacceptable acute pulmonary toxicity. Cancer 98, 978-982.

Friedrichs, C., Neyts, J., Gaspar, G., De Clercq, E. and Wutzler, P (2004) Evaluation of antiviral activity against human herpesvirus 8 (HHV-8) and Epstein-Barr virus (EBV) by a quantitative real-time PCR assay. Antiviral Res. 62, 121-123.

Frisan, T., Sjoberg, J., Dolcetti, R., Boiocchi, M., De Re, V., Carbone A., Brautbar, C., Battat, S., Biberfeld, P., Eckman, M. and et al.
(1995) Local suppression of Epstein-Barr virus (EBV)-specific cytotoxicity in biopsies of EBV-positive Hodgkin's disease. Blood 86, 1493-1501

Gediya, L. K., Khandelwal, A., Patel, J., Belosay, A., Sabnis, G., Mehta, J., Purushottamachar, P. and Njar, V. C. (2008) Design, synthesis, and evaluation of novel mutual prodrugs (hybrid drugs) of all-transretinoic acid and histone deacetylase inhibitors with enhanced anticancer activities in breast and prostate cancer cells in vitro. J. Med. Chem. 51, 3895-3904.

Gershburg, E., Hong, K. and Pagano, J. S. (2004) Effects of maribavir and selected indolocarbazoles on Epstein-Barr virus protein kinase BGLF4 and on viral lytic replication. Antimicrob.Agents Chemother. 48, 1900-1903.

Gershburg, E. and Pagano, J. S. (2002) Phosphorylation of the Epstein-Barr virus (EBV) DNA polymerase processivity factor EA-D by the EBV-encoded protein kinase and effects of the L-riboside benzimidazole 1263W94. J. Virol. 76, 998-1003.

Gires, O., Zimber-Strobl, U., Gonnella, R., Ueffing, M., Marschall, G., Zeidler, R., Pich, D. and Hammerschmidt, W. (1997) Latent membrane protein 1 of Epstein-Barr virus mimics a constitutively active receptor molecule. EMBO J. 16, 6131-6140.

Glozak, M. A., Sengupta, N., Zhang, X. and Seto, E. (2005) Acetylation and deacetylation of non-histone proteins. Gene 363, 15-23.

Gottschalk, S., Edwards, O. L., Sili, U., Huls, M. H., Goltsova, T., Davis, A. R., Heslop, H. E. and Rooney, C. M. (2003) Generating CTLs against the subdominant Epstein-Barr virus LMP1 antigen for the adoptive immunotherapy of EBV-associated malignancies. Blood 101, 1905-1912.

Grasser, F. A., Murray, P. G., Kremmer, E., Klein, K., Remberger, K., Feiden, W., Reynolds, G., Niedobitek, G., Young, L. S. and Mueller-Lantzsch, N. (1994) Monoclonal antibodies directed against the Epstein-Barr virus-encoded nuclear antigen 1 (EBNA1): immunohistologic detection of EBNA1 in the malignant cells of Hodgkin's disease. Blood 84, 3792-3798.

Gregorovic, G., Bosshard, R., Karstegl, C. E., White, R. E., Pattle, S., Chiang, A. K., Dittrich-Breiholz, O., Kracht, M., Russ, R. and Farrell, P. J. (2011) Cellular gene expression that correlates with EBER expression in Epstein-Barr Virus-infected lymphoblastoid cell lines. J. Virol. 85, 3535-3545.

Gutensohn, N. and Cole, P. (1980) Epidemiology of Hodgkin's disease. Semin. Oncol. 7, 92-102.

Hartline, C. B., Harden, E. A., Williams-Aziz, S. L., Kushner, N. L., Brideau, R. J. and Kern, E. R. (2005) Inhibition of herpesvirus replication by a series of 4-oxo-dihydroquinolines with viral polymerase activity. Antiviral Res. 65, 97-105.

Herbst, H., Dallenbach, F., Hummel, M., Niedobitek, G., Pileri, S., Muller-Lantzsch, N. and Stein, H. (1991) Epstein-Barr virus latent membrane protein expression in Hodgkin and Reed-Sternberg cells. Proc. Natl. Acad. Sci. USA 88, 4766-4770.

Herbst, H., Steinbrecher, E., Niedobitek, G., Young, L. S., Brooks, L., Muller-Lantzsch, N. and Stein, H. (1992) Distribution and phenotype of Epstein-Barr virus-harboring cells in Hodgkin's disease. Blood 80, 484-491.

Ho, J. W., Liang, R. H. and Srivastava, G. (1999) Differential cytokine expression in EBV positive peripheral T cell lymphomas. Mol. Pathol. 52, 269-274.

Hoppe, R. T., Horning, S. J., Hancock, S. L. and Rosenberg, S. A. (1989) Current Stanford clinical trials for Hodgkin's disease. Recent Results Cancer Res. 117, 182-190.

Hoppe, R. T., Horning, S. J. and Rosenberg, S. A. (1985) The concept, evolution and preliminary results of the current Stanford clinical trials for Hodgkin's disease. Cancer Surv. 4, 459-475.

Hsieh, D. J., Camiolo, S. M. and Yates, J. L. (1993) Constitutive binding of EBNA1 protein to the Epstein-Barr virus replication origin, oriP, with distortion of DNA structure during latent infection. EMBO J. 12, 4933-4944.

Humme, S., Reisbach, G., Feederle, R., Delecluse, H. J., Bousset, K., Hammerschmidt, W. and Schepers, A. (2003) The EBV nuclear antigen 1 (EBNA1) enhances $B$ cell immortalization several thousandfold. Proc. Natl. Acad. Sci. USA 100, 10989-10994.

Hummel, M., Anagnostopoulos, I., Dallenbach, F., Korbjuhn, P., Dimmler, C. and Stein, H. (1992) EBV infection patterns in Hodgkin's 
disease and normal lymphoid tissue: expression and cellular localization of EBV gene products. Br. J. Haematol. 82, 689-694.

Iwakiri, D., Eizuru, Y., Tokunaga, M. and Takada, K. (2003) Autocrine growth of Epstein-Barr virus-positive gastric carcinoma cells mediated by an Epstein-Barr virus-encoded small RNA. Cancer Res. 63, 7062-7067.

Iwakiri, D., Sheen, T. S., Chen, J. Y., Huang, D. P. and Takada, K. (2005) Epstein-Barr virus-encoded small RNA induces insulin-like growth factor 1 and supports growth of nasopharyngeal carcinomaderived cell lines. Oncogene 24, 1767-1773.

Iwakiri, D. and Takada, K. (2010) Role of EBERs in the pathogenesis of EBV infection. Adv. Cancer Res. 107, 119-136.

Iwakiri, D., Zhou, L., Samanta, M., Matsumoto, M., Ebihara, T., Seya, T., Imai, S., Fujieda, M., Kawa, K. and Takada, K. (2009) EpsteinBarr virus (EBV)-encoded small RNA is released from EBV-infected cells and activates signaling from Toll-like receptor 3. J. Exp. Med. 206, 2091-2099.

Izumi, K. M. and Kieff, E. D. (1997) The Epstein-Barr virus oncogene product latent membrane protein 1 engages the tumor necrosis factor receptor-associated death domain protein to mediate $B$ lymphocyte growth transformation and activate NF-kappaB. Proc. Natl. Acad. Sci. USA 94, 12592-12597.

Jarrett, R. F., Stark, G. L., White, J., Angus, B., Alexander, F. E., Krajewski, A. S., Freeland, J., Taylor, G. M. and Taylor, P. R. (2005) Impact of tumor Epstein-Barr virus status on presenting features and outcome in age-defined subgroups of patients with classic Hodgkin lymphoma: a population-based study. Blood 106, 2444-2451.

Jona, A., Khaskhely, N., Buglio, D., Shafer, J. A., Derenzini, E., Bollard, C. M., Medeiros, L. J., Illes, A., Ji, Y. and Younes, A. (2011) The histone deacetylase inhibitor entinostat (SNDX-275) induces apoptosis in Hodgkin lymphoma cells and synergizes with $\mathrm{Bcl}-2$ family inhibitors. Exp. Hematol. [Epub ahead of print]

Jundt, F., Raetzel, N., Muller, C., Calkhoven, C. F., Kley, K., Mathas, S., Lietz, A., Leutz, A. and Dorken, B. (2005) A rapamycin derivative (everolimus) controls proliferation through down-regulation of truncated CCAAT enhancer binding protein b and NF-kB activity in Hodgkin and anaplastic large cell lymphomas. Blood 106, 18011807

Jung, D. and Dorr, A. (1999) Single-dose pharmacokinetics of valganciclovir in HIV- and CMV-seropositive subjects. J. Clin. Pharmacol. 39, 800-804.

Kieff, E. (1996) Epstein-Barr virus and its replication. Lippincott-Raven Publishers, Philadelphia, PA.

Kira, T., Grill, S. P., Dutschman, G. E., Lin, J. S., Qu, F., Choi, Y., Chu, C. K. and Cheng, Y. C. (2000) Anti-Epstein-Barr virus (EBV) activity of beta-L-5-iododioxolane uracil is dependent on EBV thymidine kinase. Antimicrob. Agents. Chemother. 44, 3278-3284.

Kirschbaum, M. H., Goldman, B. H., Zain, J. M., Cook, J. R., Rimsza L. M., Forman, S. J. and Fisher, R. I. (2011) A Phase 2 Study of Vorinostat for Treatment of Relapsed or Refractory Hodgkin Lymphoma: Southwest Oncology Group Study S0517. Leuk. Lymphoma. [Epub ahead of print]

Kitagawa, N., Goto, M., Kurozumi, K., Maruo, S., Fukayama, M. Naoe, T., Yasukawa, M., Hino, K., Suzuki, T., Todo, S. and Takada, K. (2000) Epstein-Barr virus-encoded poly(A)(-) RNA supports Burkitt's lymphoma growth through interleukin-10 induction. EMBO J. $19,6742-6750$

Klimm, B., Schnell, R., Diehl, V. and Engert, A. (2005) Current treatment and immunotherapy of Hodgkin's Iymphoma. Haematologica 90, 1680-1692

Komano, J., Maruo, S., Kurozumi, K., Oda, T. and Takada, K. (1999) Oncogenic role of Epstein-Barr virus-encoded RNAs in Burkitt's lymphoma cell line Akata. J. Virol. 73, 9827-9831.

Kung, C. P., Meckes, D. G., Jr. and Raab-Traub, N. (2011) EpsteinBarr virus LMP1 activates EGFR, STAT3, and ERK through effects on PKCdelta. J. Virol. 85, 4399-4408.

Kuppers, R. (2003) Somatic hypermutation and B cell receptor selection in normal and transformed human B cells. Ann. NY Acad. Sci. 987, 173-179.

Kuppers, R. (2009) Molecular biology of Hodgkin lymphoma. Hematology Am. Soc. Hematol. Educ. Program 491-496.

Kuppers, R., Rajewsky, K., Zhao, M., Simons, G., Laumann, R., Fisch- er, R. and Hansmann, M. L. (1994) Hodgkin disease: Hodgkin and Reed-Sternberg cells picked from histological sections show clonal immunoglobulin gene rearrangements and appear to be derived from B cells at various stages of development. Proc. Natl. Acad. Sci. USA 91, 10962-10966.

Lambert, S. L. and Martinez, O. M. (2007) Latent membrane protein 1 of EBV activates phosphatidylinositol 3-kinase to induce production of IL-10. J. Immunol. 179, 8225-8234.

Lamprecht, B., Kreher, S., Anagnostopoulos, I., Johrens, K., Monteleone, G., Jundt, F., Stein, H., Janz, M., Dorken, B. and Mathas, S. (2008) Aberrant expression of the Th2 cytokine IL-21 in Hodgkin lymphoma cells regulates STAT3 signaling and attracts Treg cells via regulation of MIP-3alpha. Blood 112, 3339-3347.

Law, C. L., Gordon, K. A., Collier, J., Klussman, K., McEarchern, J. A., Cerveny, C. G., Mixan, B. J., Lee, W. P., Lin, Z., Valdez, P., Wahl, A. F. and Grewal, I. S. (2005) Preclinical antilymphoma activity of a humanized anti-CD40 monoclonal antibody, SGN-40. Cancer Res. 65, 8331-8338.

Lee, I. S., Kim, S. H., Song, H. G. and Park, S. H. (2003) The molecular basis for the generation of Hodgkin and Reed-Sternberg cells in Hodgkin's lymphoma. Int. J. Hematol. 77, 330-335.

Leoncini, L., Spina, D., Nyong'o, A., Abinya, O., Minacci, C., Disanto, A., De Luca, F., De Vivo, A., Sabattini, E., Poggi, S., Pileri, S. and Tosi, P. (1996) Neoplastic cells of Hodgkin's disease show differences in EBV expression between Kenya and Italy. Int. J. Cancer 65, 781-784.

Levine, P. H., Ablashi, D. V., Berard, C. W., Carbone, P. P., Waggoner, D. E. and Malan, L. (1971) Elevated antibody titers to Epstein-Barr virus in Hodgkin's disease. Cancer 27, 416-421.

Levitskaya, J., Coram, M., Levitsky, V., Imreh, S., Steigerwald-Mullen, P. M., Klein, G., Kurilla, M. G. and Masucci, M. G. (1995) Inhibition of antigen processing by the internal repeat region of the EpsteinBarr virus nuclear antigen-1. Nature 375, 685-688.

Levitskaya, J., Sharipo, A., Leonchiks, A., Ciechanover, A. and Masucci, M. G. (1997) Inhibition of ubiquitin/proteasome-dependent protein degradation by the Gly-Ala repeat domain of the EpsteinBarr virus nuclear antigen 1. Proc. Natl. Acad. Sci. USA 94, 1261612621.

Longnecker, R. (2000) Epstein-Barr virus latency: LMP2, a regulator or means for Epstein-Barr virus persistence? Adv. Cancer Res. 79, $175-200$

Longnecker, R. and Kieff, E. (1990) A second Epstein-Barr virus membrane protein (LMP2) is expressed in latent infection and colocalizes with LMP1. J. Virol. 64, 2319-2326.

Longo, D. L., Young, R. C., Wesley, M., Hubbard, S. M., Duffey, P. L., Jaffe, E. S. and DeVita, V. T., Jr. (1986) Twenty years of MOPP therapy for Hodgkin's disease. J. Clin. Oncol. 4, 1295-1306.

Lu, J., Murakami, M., Verma, S. C., Cai, Q., Haldar, S., Kaul, R., Wasik, M. A., Middeldorp, J. and Robertson, E. S. (2011) Epstein-Barr Virus nuclear antigen 1 (EBNA1) confers resistance to apoptosis in EBV-positive B-lymphoma cells through up-regulation of survivin. Virology 410, 64-75.

Luqman, M., Klabunde, S., Lin, K., Georgakis, G. V., Cherukuri, A., Holash, J., Goldbeck, C., Xu, X., Kadel, E. E., 3rd, Lee, S. H., Aukerman, S. L., Jallal, B., Aziz, N., Weng, W. K., Wierda, W., O'Brien, S. and Younes, A. (2008) The antileukemia activity of a human antiCD40 antagonist antibody, HCD122, on human chronic lymphocytic leukemia cells. Blood 112, 711-720.

Lutzky, V. P., Corban, M., Heslop, L., Morrison, L. E., Crooks, P., Hall, D. F., Coman, W. B., Thomson, S. A. and Moss, D. J. (2010) Novel approach to the formulation of an Epstein-Barr virus antigen-based nasopharyngeal carcinoma vaccine. J. Virol. 84, 407-417.

Lynch, D. T., Zimmerman, J. S. and Rowe, D. T. (2002) Epstein-Barr virus latent membrane protein $2 B$ (LMP2B) co-localizes with LMP2A in perinuclear regions in transiently transfected cells. J. Gen. Virol. 83, 1025-1035.

Maggioncalda, A., Malik, N., Shenoy, P., Smith, M., Sinha, R. and Flowers, C. R. (2011) Clinical, molecular, and environmental risk factors for hodgkin lymphoma. Adv. Hematol. 2011, 736261.

Marshall, N. A., Vickers, M. A. and Barker, R. N. (2003) Regulatory T cells secreting IL-10 dominate the immune response to EBV latent membrane protein 1. J. Immunol. 170, 6183-6189. 
Masucci, M. G., Zhang, Q. J., Gavioli, R., De Campos-Lima, P. O. Murray, R. J., Brooks, J., Griffin, H., Ploegh, H. and Rickinson, A. B. (1992) Immune escape by Epstein-Barr virus (EBV) carrying Burkitt's lymphoma: in vitro reconstitution of sensitivity to EBVspecific cytotoxic T cells. Int. Immunol. 4, 1283-1292.

Meyer, R. M., Ambinder, R. F. and Stroobants, S. (2004) Hodgkin's lymphoma: evolving concepts with implications for practice. Hematology Am. Soc. Hematol. Educ. Program 184-202.

Minucci, S. and Pelicci, P. G. (2006) Histone deacetylase inhibitors and the promise of epigenetic (and more) treatments for cancer. Nat. Rev. Cancer 6, 38-51.

Morrison, J. A., Klingelhutz, A. J. and Raab-Traub, N. (2003) EpsteinBarr virus latent membrane protein $2 \mathrm{~A}$ activates beta-catenin signaling in epithelial cells. J. Virol. 77, 12276-12284.

Murray, P. G., Young, L. S., Rowe, M. and Crocker, J. (1992) Immunohistochemical demonstration of the Epstein-Barr virus-encoded latent membrane protein in paraffin sections of Hodgkin's disease. J. Pathol. 166, 1-5.

Niedobitek, G., Kremmer, E., Herbst, H., Whitehead, L., Dawson, C. W., Niedobitek, E., von Ostau, C., Rooney, N., Grasser, F. A. and Young, L. S. (1997) Immunohistochemical detection of the EpsteinBarr virus-encoded latent membrane protein 2A in Hodgkin's disease and infectious mononucleosis. Blood 90, 1664-1672.

O'Connor, O. A. (2005) Developing new drugs for the treatment of lymphoma. Eur. J. Haematol. 75, 150-158.

Oflazoglu, E., Kissler, K. M., Sievers, E. L., Grewal, I. S. and Gerber, H P. (2008) Combination of the anti-CD30-auristatin-E antibody-drug conjugate (SGN-35) with chemotherapy improves antitumour activity in Hodgkin lymphoma. Br. J. Haematol. 142, 69-73.

Oki, Y. and Younes, A. (2010) Does rituximab have a place in treating classic hodgkin lymphoma? Curr. Hematol. Malig. Rep. 5, 135-139.

Oza, A. M., Ganesan, T. S., Leahy, M., Gregory, W., Lim, J., Dadiotis, L., Barbounis, V., Jones, A. E., Amess, J., Stansfeld, A. G. and et al. (1993) Patterns of survival in patients with Hodgkin's disease: long follow up in a single centre. Ann. Oncol. 4, 385-392.

Pagano, J. S. (1995) Antiviral Chemotherapy. John Wiley \& Sons Ltd.

Pagano, J. S., Sixbey, J. W. and Lin, J. C. (1983) Acyclovir and Epstein-Barr virus infection. J. Antimicrob. Chemother. 12, 113-121.

Pallesen, G., Hamilton-Dutoit, S. J., Rowe, M. and Young, L. S. (1991) Expression of Epstein-Barr virus latent gene products in tumour cells of Hodgkin's disease. Lancet 337, 320-322.

Pan, J., Zhang, Q., Zhou, J., Ma, D., Xiao, X. and Wang, D. W. (2009) Recombinant adeno-associated virus encoding Epstein-Barr virus latent membrane proteins fused with heat shock protein as a potential vaccine for nasopharyngeal carcinoma. Mol. Cancer Ther. 8, 2754-2761.

Panousis, C. G. and Rowe, D. T. (1997) Epstein-Barr virus latent membrane protein 2 associates with and is a substrate for mitogen-activated protein kinase. J. Virol. 71, 4752-4760.

Paramita, D. K., Fatmawati, C., Juwana, H., van Schaijk, F. G., Fachiroh, J., Haryana, S. M. and Middeldorp, J. M. (2011) Humoral immune responses to Epstein-Barr virus encoded tumor associated proteins and their putative extracellular domains in nasopharyngeal carcinoma patients and regional controls. J. Med. Virol. 83 665-678.

Pileri, S. A., Ascani, S., Leoncini, L., Sabattini, E., Zinzani, P. L., Piccaluga, P. P., Pileri, A. Jr., Giunti, M., Falini, B., Bolis, G. B. and Stein, H. (2002) Hodgkin's lymphoma: the pathologist's viewpoint. J. Clin. Pathol. 55, 162-176.

Pinkus, G. S., Lones, M., Shintaku, I. P. and Said, J. W. (1994) Immunohistochemical detection of Epstein-Barr virus-encoded latent membrane protein in Reed-Sternberg cells and variants of Hodgkin's disease. Mod. Pathol. 7, 454-461.

Poppema, S., Delsol, G., Pileri, S. A., Stein, H., Swerdlow, S.H., Warnke, R. A. and Jaffe, E. S. (2008) Nodular lymphocyte predominant Hodgkin lymphoma. WHO Classification of Tumours of the Haemotopoietic and Lymphoid Tissues. 323-325. IARC Press, Lyon.

Poppema, S., Potters, M., Emmens, R., Visser, L. and van den Berg, A. (1999) Immune reactions in classical Hodgkin's lymphoma. Semin. Hematol. 36, 253-259.

Purifoy, D. J., Beauchamp, L. M., de Miranda, P., Ertl, P., Lacey, S., Roberts, G., Rahim, S.G., Darby, G., Krenitsky, T.A. and Powell,
K. L. (1993) Review of research leading to new anti-herpesvirus agents in clinical development: valaciclovir hydrochloride (256U, the L-valyl ester of acyclovir) and $882 \mathrm{C}$, a specific agent for varicella zoster virus. J. Med. Virol. Suppl 1, 139-145.

Reinstein, E. and Ciechanover, A. (2006) Narrative review: protein degradation and human diseases: the ubiquitin connection. Ann. Intern. Med. 145, 676-684.

Rickinson, A. B., Gregory, C. D. and Young, L. S. (1987) Viruses and cancer risks: outgrowth of Epstein-Barr virus-positive Burkitt's lymphoma in the immune host. Med. Oncol. Tumor Pharmacother. 4, 177-186.

Rickinson, A. B., Murray, R. J., Brooks, J., Griffin, H., Moss, D. J. and Masucci, M. G. (1992) T cell recognition of Epstein-Barr virus associated lymphomas. Cancer Surv. 13, 53-80.

Robak, T. (2008) Novel monoclonal antibodies for the treatment of chronic lymphocytic leukemia. Curr. Cancer Drug Targets 8, 156171.

Rosa, M. D., Gottlieb, E., Lerner, M. R. and Steitz, J. A. (1981) Striking similarities are exhibited by two small Epstein-Barr virus-encoded ribonucleic acids and the adenovirus-associated ribonucleic acids VAI and VAll. Mol. Cell Biol. 1, 785-796.

Rowe, M., Rooney, C. M., Edwards, C. F., Lenoir, G. M. and Rickinson, A. B. (1986) Epstein-Barr virus status and tumour cell phenotype in sporadic Burkitt's lymphoma. Int. J. Cancer 37, 367-373.

Samanta, M., Iwakiri, D., Kanda, T., Imaizumi, T. and Takada, K. (2006) EB virus-encoded RNAs are recognized by RIG-I and activate signaling to induce type I IFN. EMBO J. 25, 4207-4214.

Samanta, M., Iwakiri, D. and Takada, K. (2008) Epstein-Barr virusencoded small RNA induces IL-10 through RIG-I-mediated IRF-3 signaling. Oncogene 27, 4150-4160.

Scholle, F., Bendt, K. M. and Raab-Traub, N. (2000) Epstein-Barr virus LMP2A transforms epithelial cells, inhibits cell differentiation, and activates Akt. J. Virol. 74, 10681-10689.

Shah, K. M., Stewart, S. E., Wei, W., Woodman, C. B., O'Neil, J. D., Dawson, C. W. and Young, L. S. (2009) The EBV-encoded latent membrane proteins, LMP2A and LMP2B, limit the actions of interferon by targeting interferon receptors for degradation. Oncogene 28, 3903-3914.

Shah, K. M. and Young, L. S. (2009) Epstein-Barr virus and carcinogenesis: beyond Burkitt's lymphoma. Clin. Microbiol. Infect. 15, 982-988.

Shimabukuro-Vornhagen, A., Haverkamp, H., Engert, A., Balleisen, L., Majunke, P., Heil, G., Eich, H. T., Stein, H., Diehl, V. and Josting, A. (2005) Lymphocyte-rich classical Hodgkin's lymphoma: clinical presentation and treatment outcome in 100 patients treated within German Hodgkin's Study Group trials. J. Clin. Oncol. 23, 57395745 .

Sing, A. P., Ambinder, R. F., Hong, D. J., Jensen, M., Batten, W., Petersdorf, E. and Greenberg, P. D. (1997) Isolation of Epstein-Barr virus (EBV)-specific cytotoxic T lymphocytes that lyse Reed-Sternberg cells: implications for immune-mediated therapy of EBV+ Hodgkin's disease. Blood 89, 1978-1986.

Slack, G. W., Ferry, J. A., Hasserjian, R. P., Sohani, A. R., Longtine, J. A., Harris, N. L. and Zukerberg, L. R. (2009) Lymphocyte depleted Hodgkin lymphoma: an evaluation with immunophenotyping and genetic analysis. Leuk. Lymphoma 50, 937-943.

Smith, C., Cooper, L., Burgess, M., Rist, M., Webb, N., Lambley, E., Tellam, J., Marlton, P., Seymour, J. F., Gandhi, M. and Khanna, R. (2006) Functional reversion of antigen-specific CD8+ T cells from patients with Hodgkin lymphoma following in vitro stimulation with recombinant polyepitope. J. Immunol. 177, 4897-4906.

Specht, L., Gray, R. G., Clarke, M. J. and Peto, R. (1998) Influence of more extensive radiotherapy and adjuvant chemotherapy on longterm outcome of early-stage Hodgkin's disease: a meta-analysis of 23 randomized trials involving 3,888 patients. International Hodgkin's Disease Collaborative Group. J. Clin. Oncol. 16, 830-843.

Spitz, M. R., Sider, J. G., Johnson, C. C., Butler, J. J., Pollack, E. S. and Newell, G. R. (1986) Ethnic patterns of Hodgkin's disease incidence among children and adolescents in the United States, 197382. J. Natl. Cancer Inst. 76, 235-239.

Stark, G. L., Wood, K. M., Jack, F., Angus, B., Proctor, S. J. and Taylor, P. R. (2002) Hodgkin's disease in the elderly: a population-based 
study. Br. J. Haematol. 119, 432-440.

Steven, N. M., Leese, A. M., Annels, N. E., Lee, S. P. and Rickinson, A B. (1996) Epitope focusing in the primary cytotoxic T cell response to Epstein-Barr virus and its relationship to T cell memory. J. Exp. Med. 184, 1801-1813.

Straus, D. J., Johnson, J. L., LaCasce, A. S., Bartlett, N. L., Kostakoglu, L., Hsi, E. D., Schoder, H., Hall, N. C., Jung, S. H., Canellos, G. P., Schwartz, L. H., Takvorian, R. W., Juweid, M. E. and Cheson, B.D. (2011) Doxorubicin, vinblastine, and gemcitabine (CALGB 50203) for stage I/II nonbulky Hodgkin lymphoma: pretreatment prognostic factors and interim PET. Blood 117, 5314-5320.

Su, Z., Peluso, M. V., Raffegerst, S. H., Schendel, D. J. and Roskrow, M. A. (2001) The generation of LMP2a-specific cytotoxic T lymphocytes for the treatment of patients with Epstein-Barr virus-positive Hodgkin disease. Eur. J. Immunol. 31, 947-958.

Swaminathan, S., Tomkinson, B. and Kieff, E. (1991) Recombinant Epstein-Barr virus with small RNA (EBER) genes deleted transforms lymphocytes and replicates in vitro. Proc. Natl. Acad. Sci. USA 88, 1546-1550.

Tarasenko, N., Nudelman, A., Tarasenko, I., Entin-Meer, M., Hass-Kogan, D., Inbal, A. and Rephaeli, A. (2008) Histone deacetylase inhibitors: the anticancer, antimetastatic and antiangiogenic activities of AN-7 are superior to those of the clinically tested AN-9 (Pivanex). Clin. Exp. Metastasis 25, 703-716.

Taylor, G. S., Haigh, T. A., Gudgeon, N. H., Phelps, R. J., Lee, S. P., Steven, N. M. and Rickinson, A. B. (2004) Dual stimulation of Epstein-Barr Virus (EBV)-specific CD4+- and CD8+-T-cell responses by a chimeric antigen construct: potential therapeutic vaccine for EBV-positive nasopharyngeal carcinoma. J. Virol. 78, 768-778.

Tellam, J., Connolly, G., Webb, N., Duraiswamy, J. and Khanna, R. (2003) Proteasomal targeting of a viral oncogene abrogates oncogenic phenotype and enhances immunogenicity. Blood 102, 45354540.

Tellam, J., Sherritt, M., Thomson, S., Tellam, R., Moss, D. J., Burrows, S. R., Wiertz, E. and Khanna, R. (2001) Targeting of EBNA1 for rapid intracellular degradation overrides the inhibitory effects of the Gly-Ala repeat domain and restores CD8+ T cell recognition. J. Biol. Chem. 276, 33353-33360.

Thomas, R. K., Re, D., Wolf, J. and Diehl, V. (2004) Part I: Hodgkin's lymphoma--molecular biology of Hodgkin and Reed-Sternberg cells. Lancet Oncol. 5, 11-18.

Thompson, L. D., Fisher, S. I., Chu, W. S., Nelson, A. and Abbondanzo, S. L. (2004) HIV-associated Hodgkin lymphoma: a clinicopathologic and immunophenotypic study of 45 cases. Am. J. Clin. Pathol. 121, 727-738.

Timms, J. M., Bell, A., Flavell, J. R., Murray, P. G., Rickinson, A. B., Traverse-Glehen, A., Berger, F. and Delecluse, H. J. (2003) Target cells of Epstein-Barr-virus (EBV)-positive post-transplant lymphoproliferative disease: similarities to EBV-positive Hodgkin's lymphoma. Lancet 361, 217-223.

Tobery, T. and Siliciano, R. F. (1999) Cutting edge: induction of enhanced CTL-dependent protective immunity in vivo by $\mathrm{N}$-end rule targeting of a model tumor antigen. J. Immunol. 162, 639-642.

van der Horst, C., Joncas, J., Ahronheim, G., Gustafson, N., Stein, G., Gurwith, M., Fleisher, G., Sullivan, J., Sixbey, J., Roland, S. and et al. (1991) Lack of effect of peroral acyclovir for the treatment of acute infectious mononucleosis. J. Infect. Dis. 164, 788-792.

Varshavsky, A. (1996) The N-end rule: functions, mysteries, uses.
Proc. Natl. Acad. Sci. USA 93, 12142-12149.

Weinreb, M., Day, P. J., Niggli, F., Green, E. K., Nyong'o, A. O., Othieno-Abinya, N. A., Riyat, M. S., Raafat, F. and Mann, J. R. (1996) The consistent association between Epstein-Barr virus and Hodgkin's disease in children in Kenya. Blood 87, 3828-3836.

Weiss, L. M., Chan, J. K. C., MacLennan, K. and Warnke, R. A. (1999) Pathology of classical Hodgkin's disease. Lippincott Williams \& Wilkins, Philadelphia, PA.

Weiss, L. M., Chen, Y. Y., Liu, X. F. and Shibata, D. (1991) Epstein-Barr virus and Hodgkin's disease. A correlative in situ hybridization and polymerase chain reaction study. Am. J. Pathol. 139, 1259-1265.

Weiss, L. M., Movahed, L. A., Warnke, R. A. and Sklar, J. (1989) Detection of Epstein-Barr viral genomes in Reed-Sternberg cells of Hodgkin's disease. N. Engl. J. Med. 320, 502-506.

Westphal, E. M., Blackstock, W., Feng, W., Israel, B. and Kenney, S. C. (2000) Activation of lytic Epstein-Barr virus (EBV) infection by radiation and sodium butyrate in vitro and in vivo: a potential method for treating EBV-positive malignancies. Cancer Res. 60, 5781-5788.

Yajima, Y., Tanaka, A. and Nonoyama, M. (1976) Inhibition of productive replication of Epstein-Barr virus DNA by phosphonoacetic acid. Virology 71, 352-354.

Yamamoto, N., Takizawa, T., Iwanaga, Y. and Shimizu, N. (2000) Malignant transformation of $B$ lymphoma cell line BJAB by EpsteinBarr virus-encoded small RNAs. FEBS Lett. 484, 153-158.

Yee, K. W., Zeng, Z., Konopleva, M., Verstovsek, S., Ravandi, F., Ferrajoli, A., Thomas, D., Wierda, W., Apostolidou, E., Albitar, M., O'Brien, S., Andreeff, M. and Giles, F. J. (2006) Phase I/II study of the mammalian target of rapamycin inhibitor everolimus (RAD001) in patients with relapsed or refractory hematologic malignancies. Clin Cancer Res. 12, 5165-5173.

Yoshioka, M., Kikuta, H., Ishiguro, N., Ma, X. and Kobayashi, K. (2003) Unique Epstein-Barr virus (EBV) latent gene expression, EBNA promoter usage and EBNA promoter methylation status in chronic active EBV infection. J. Gen. Virol. 84, 1133-1140.

Younes, A. (2009) Novel treatment strategies for patients with relapsed classical Hodgkin lymphoma. Hematology Am. Soc. Hematol. Educ. Program 507-519.

Younes, A., Garg, A. and Aggarwal, B. B. (2003) Nuclear transcription factor-kappaB in Hodgkin's disease. Leuk. Lymphoma 44, 929-935.

Young, L.S. and Rickinson, A.B. (2004). Epstein-Barr virus: 40 years on. Nat. Rev. Cancer 4, 757-768.

Zacny, V. L., Gershburg, E., Davis, M. G., Biron, K. K. and Pagano, J. S. (1999) Inhibition of Epstein-Barr virus replication by a benzimidazole L-riboside: novel antiviral mechanism of 5, 6-dichloro-2(isopropylamino)-1-beta-L-ribofuranosyl-1H-benzimidazole. J. Virol. 73, 7271-7277.

Zheng, B., Fiumara, P., Li, Y. V., Georgakis, G., Snell, V., Younes, M., Vauthey, J. N., Carbone, A. and Younes, A. (2003) MEK/ERK pathway is aberrantly active in Hodgkin disease: a signaling pathway shared by CD30, CD40, and RANK that regulates cell proliferation and survival. Blood 102, 1019-1027.

Zheng, B., Georgakis, G. V., Li, Y., Bharti, A., McConkey, D., Aggarwal, B. B. and Younes, A. (2004) Induction of cell cycle arrest and apoptosis by the proteasome inhibitor PS-341 in Hodgkin disease cell lines is independent of inhibitor of nuclear factor-kappaB mutations or activation of the CD30, CD40, and RANK receptors. Clin. Cancer Res. 10, 3207-3215. 